\title{
6 \\ The law of rahui in the Society Islands
}

Tamatoa Bambridge

Scholars consider tapu and the rahui to be fundamental institutions in pre-European societies across all parts of the Polynesian Triangle. ${ }^{1}$ Yet very little is known about them in contemporary Polynesia as far as legal and organisational issues are concerned. Tapu is a term that signifies an object, person or location that was 'marked', 'contained', 'restricted', or 'put aside'. In one sense, tapu is the state of a person, a thing, a place where mana (divine power) is present. A second meaning signifies 'forbidden to certain categories of persons in certain contexts'. This term may have been translated as 'sacred', but we need to question this assertion given that Western intellectual schema posing oppositions between sacred and profane elements cannot explain categories of the Polynesian cosmogonies. ${ }^{2}$ If tapu has been

1 Smith, J., 1974. Tapu Removal in Maori Religion, Memoir no. 40. Wellington: The Polynesian Society; Best, E., 1904. 'Notes on the custom of Rahui, its application and manipulation, as also its supposed powers, its rites, invocations and superstitions'. Journal of the Polynesian Society 13(2): 83-88; Oliver, D., 1974. Ancient Tahitian Society. 3 vols. Honolulu: The University Press of Hawai'i; Devatine, F., 1992. Tapu et Rahui. Assises de la Recherche en Polynésie française, Document dactylographié, non publié. Papeete: Académie tahitienne.

2 Rigo, B., 2004. Altérité polynésienne ou les métamorphoses de l'espace-temps. Paris: CNRS Editions. 
extensively analysed in the secondary literature, ${ }^{3}$ it is not the case with rahui. Rahui generally refers to the ability of a chief to order a tapu on a specific place or a particular resource, for a limited period of time. ${ }^{4}$

The relative wealth of descriptions of rahui in primary sources and comparatively limited attention in secondary modern sources has resulted in the misrepresentation of rahui and related concepts such as mana and tapu, which, in turn, has resulted in an overly structural understanding of Polynesian sociopolitical chieftainship. Theoretical approaches advocated by Sahlins, ${ }^{5}$ and more recently by Hviding, ${ }^{6}$ imply a model of chieftainship based on a structural and functional model of society. On the contrary, the careful analysis of primary sources from the Society Islands shows a more varied use of tapu and rahui that depends on contexts and network relationships of one chief ramage with others and across sociopolitical groups. For these reasons, it is useful to return to the primary sources in order to fill the gaps and revise modern representations of rahui.

Rahui is often represented as having a supreme authority. ${ }^{7}$ Fraselle ${ }^{8}$ and Oliver ${ }^{9}$ described - in Aotearoa New Zealand and Tahiti respectively - some manifestations of rahui during the nineteenth century. The traditions of rahui were as rich and diverse as the different regions of Polynesia. For example, in the Society Islands alone, it has been noted that a leader would establish a rahui on the marae

3 Hocart A.M., 1914. 'Mana'. Man 14: 97-101; Firth, R., 1940. 'The analysis of mana: an empirical approach'. Journal of the Polynesian Society, 49: 483-510; Keesing, R.M., 1984. 'Rethinking mana'. Journal of Anthropological Research 40(1): 137-56; Hooper S.J.P., 1996. 'Who are the chiefs? Chiefship in Lau, Eastern Fiji'. In R. Feinberg \& K. Watson-Gegeo (eds), Leadership and Change in the Western Pacific: Essays presented to Sir Raymond Firth on the Occasion of his Ninetieth Birthday, LES Monographs on Social Anthropology 66. Athlone Press, pp. 239-71; Shore, B., 1989. 'Mana and Tapu: a new synthesis'. In A. Howard \& R. Borofsky (eds), Developments in Polynesian Ethnology. Honolulu: University of Hawai'i Press, pp. 137-74; Rainbird, P., 2003. 'Taking the Tapu. Defining Micronesia by absence'. Journal of the Pacific History 38(2): 237-50.

4 Oliver, D., 1974.

5 Sahlins, M.D., 1958. Social Stratification in Polynesia. Seattle: University of Washington Press, pp. 140-49.

6 Hviding, E,. 1996. Guardians of Marovo Lagoon: Practice, Place, and Politics in Maritime Melanesia. Honolulu: University of Hawai'i Press.

7 Ellis, W., 1829. Polynesian Researches. vol. 2. London: Fisher, Son and Jackson; Morrison, J., 1966. Le Journal de James Morrison, second maître à bord le la Bounty. Traduit de l'anglais par B. JAUNEZ. Paris: Musée de l'Homme.

8 Fraser, 1892. 'Notes and queries'. Journal of the Polynesian Society 1(4): 273-76.

9 Oliver, D., 1974. 
(temple) on a child's birth, ${ }^{10}$ after a bloody war, or during ceremonies such as pai atua (god worship) and taurua ari'i (chief feast). On these occasions, the production of common resources was brought to a standstill for a short period. According to French nineteenth-century ethnographer De Bovis, ${ }^{11}$ the rahui embodied a new form of tapu in the Society Islands. The English missionary William Ellis, ${ }^{12}$ however, recalled that tapu operated on a spiritual and religious level whereas the rahui applied mostly to material elements.

The breadth and diversity of the traditions of rahui makes it interesting and necessary to address the phenomenon more closely, especially in the field of legal anthropology.

The literature involving the Society Islands is often vague and contradictory in regard to rahui. How the population came to justify the implementation of a rahui on a specific territory, and how leaders brought legitimacy to the sanctions they imposed are still unclear. As to the decision to impose a rahui, the majority of primary sources attribute the responsibility to the ari'i (chief). These sources include published observations made by nineteenth-century European witnesses ${ }^{13}$ sources based on recollections of traditional authorities, ${ }^{14}$ and secondary works that utilise references from both of the former categories. ${ }^{15}$

The purpose of this chapter is to describe, in legal anthropological terms, the numerous traditions of pre-European rahui within various contexts. Three difficulties arise in producing such a categorisation.

10 Adams, H., 1964. Mémoires d'Ari'i Tamai, Paris: Publication de la Société des Océanistes no. 12, Musée de l'Homme, p. 27.

11 de Bovis, E., 1978. Etat de la société tahitienne à l'arrivée des européens. Publication no. 4. Tahiti: Société des Études Océaniennes.

12 Ellis, 1829.

13 Rodriguez, M., 1995. Les Espagnols à Tahiti (1772-1776). Publication de la société des Océanistes no. 45. Paris: Musée de l'Homme; Ellis, 1829; de Bovis, 1978; Tyerman, D., \& Bennet, G., 1832. Journal of Travel and Voyages by Rev. Bennet and Tyerman. 3 vols. Boston: Croker and Brewster; Davies, J., 1851. A Tahitian and English Dictionary with Introductory Remarks on the Polynesian Language and a Short Grammar of the Tahitian Dialect. Tahiti, printed at the London Missionary Society's Press; Morrison, 1966.

14 Adams, 1964; Henry, T., 1928. Ancient Tahiti, Bulletin no. 48. Honolulu: Bernice P. Bishop Museum; Pomare, T., 1971. Mémoires de Marau Taaroa, dernière reine de Tahiti, traduits par sa fille, la princesse Takau Pomare. Publication de la Société des Océanistes no. 27. Paris: Musée de l'Homme.

15 Handy, E.S.C., 1971b (1923). The Native Culture in the Marquesas. Bulletin no. 9. Bernice P. Bishop Museum, Honolulu, New York: Kraus Reprint Co; Oliver, 1974. 
First, many reports were based on romanticised stories rather than practical observations of everyday life. Moreover, in these accounts, rahui was described as a set of rules laid out and obeyed uniformly, instead of as a process defined by enactment and subject to important variation across sociopolitical groups. Second, reports from the early period of European contact were influenced by the historical context in which the authors participated. The most significant examples may be those of Takau Pomare, ${ }^{16}$ the daughter of Pomare IV, the last queen who ruled Tahiti and its dependences in the late nineteenth century, and the English missionary William Ellis, ${ }^{17}$ a member of the London Missionary Society. In many instances, both describe the rahui as they experienced it as a monopoly of the ari'i (chief). Third, the researcher is challenged by the abstract and somewhat confusing descriptions of rahui, so that it is difficult to grasp the reality of the 'living law'. ${ }^{18}$ The temptation to describe the rahui in terms of English common law (especially in the descriptions made in the early nineteenth century), and French civil law as interpreted by the high judiciary court in the second half of the nineteenth century, contradicts the description of rahui as a process determined by enactment of the chief and sociopolitical groups.

There has been a major paradigm shift in legal anthropology towards analysing law as a process ${ }^{19}$ instead of a static system of rules, especially among oral and non-centralised societies where legal pluralism was part of the social structure. ${ }^{20}$ Prior to European colonisation, with the notable exception of Tonga, Polynesian society did not know any centralisation of power, even if the possibility was a preoccupation of certain Polynesian chiefs. Legal pluralism did not exist because of the presence of a centralised state power in the late nineteenth century, but existed within and beyond such centralised polities because of the

\footnotetext{
16 Pomare, 1971.

17 Ellis, 1829, vol. 2, p. 557.

18 Ehrlich, E., 2001 (1913). Fundamental Principles of the Sociology of Law. New Brunswick: Transaction Publishers.

19 Moore, S.F., 1978. 'Law and social change: the semi-autonomous field as an appropriate subject of study'. In L. Nader (ed.), Law as Process. An Anthropological Approach. London: Routledge and Kegan Paul, pp. 54-81; Griffith, J., 1986. 'What is legal pluralism?' Journal of Legal Pluralism 24: 1-53.

20 Bambridge, T., 2005. 'Cosmogonies et juridicité en Océanie'. In Anthropologies et Droits, état des savoirs. Paris: Association française d'Anthropologie du Droit, PUF, pp. 392-95; Bambridge, Tamatoa, 2009. La terre dans l'archipel des îles Australes. Étude du pluralisme juridique et culturel en matière foncière. Institut de Recherche pour le Développement (IRD) et Aux Vents des îles.
} 
plural authorities that continued to enforce a set of rules and sanctions that might defer from one sociopolitical group to another and according to status of the sociopolitical group or groups involved. ${ }^{21}$

Most of the literature introduces the rahui as the exclusive power of a leader. Yet, in order to contextualise the tradition of rahui properly, one must take into account the structure of a non-centralised society, the social organisation, the ramage and lineages as fundamental sociopolitical institutions for understanding Oceanian societies. ${ }^{22}$ In the specific context of the Society Islands, it is important to take into account the influence of these ramages through the study of the extended families (the opu), which were often affiliated to one another. Thus, each leader could have their own form of rahui established in various designated territories. This important point has implications for core debates in Oceanic anthropology on leadership, as it moderates a structural perspective on chiefly leadership defined as 'conical clans', where absolute differentiation of the eldest brother from his younger brothers is recognised. ${ }^{23}$

After discussing the authority of the rahui on land (part I) and at sea (part II) in the Society Islands, we will analyse the extent to which the rahui seems to have been a ramified institution (part III), that is to say, an institution managed by a plurality of statuses, including the lesser status category of this Polynesian society: the manahune.

\section{Rahui: A monopoly of the ari'i?}

Discussing the term mana in a broad sense, Keesing ${ }^{24}$ indicates that it signifies efficiency of endeavour derived from divine origin, the capacity to produce an effect that goes beyond human contingencies. Mana is associated with the power of the chief. ${ }^{25}$ Shore specifies that for understanding a concept like mana, one also needs to understand

\footnotetext{
21 Bambridge, 2009.

22 Firth, R., 1965. Essays on Social Organization and Values. Monograph on Social Anthropology no. 28. University of London, London School of Economics: The Athlone Press; Petersen, G., 2007. 'Hambruch's colonial narrative.' Journal of Pacific History 42(3): 317-30.

23 Sahlins, M.D., 1958. Social Stratification in Polynesia. Seattle: University of Washington Press, p. 150.

24 Keesing, 1984.

25 Firth, 1940, p. 508.
} 
related concepts such as tapu and noa. ${ }^{26}$ Neither Keesing, Shore nor Firth mentions the concept of rahui, despite its obvious importance in the primary sources. In all cases, it is not clear how the concepts of mana and tapu are enacted across sociopolitical groups and related to higher or minor chiefs. For example, Firth calls for an empirical approach in the analysis of mana, ${ }^{27}$ but most of his work was done with the ariki (the highest statute of chief) on Tikopia, in such a way that it is never clear which chiefs are concerned with mana. ${ }^{28}$

The notion of rahui is usually classified with other sacred notions of the Polynesian cosmogony such as raa or $m o^{\prime} a .^{29}$ According to Oliver, the word rahui is used to 'to denote the restrictions, usually spiritually sanctioned, periodically laid on hogs, fruit, fish and so forth, for conservation and other purposes' ${ }^{\prime 0} \mathrm{D}$. Oliver insists on the political character of the institution rather than on it having an ecological purpose to preserve resources. ${ }^{31}$

In her mother's memoirs, Takau Pomare points out that the earliest Tahitian traditions about rahui concern Tetunae, who was the first legislator; indeed, he was called 'Tetunae, the legislator' ${ }^{32}$ Pomare recalls his precepts of rahui, transmitted to her mother:

All that is rahui must not be eaten: the turtle, the urupiti [a large fish], all the big fish of the sea and the lagoon, breast and tenderloin of pork, the first fruits of earth. All of this is reserved. These foods are banned. The rahui, prohibition of food for the arii, must be honoured by all, except one who disobeys will be punished by death.

Actually, Pomare aimed at establishing the genealogical history of her family in relation to Tetunae and, at the same time, to underline that the rahui was an institution where the ari'i had exclusive rights. Nevertheless, her recollection does not specify whether the authority of the rahui encompassed all the territories or only those linked to the ari'i family members.

\footnotetext{
26 Shore, 1989.

27 Firth, 1940, pp. 482-507.

28 See also Petersen G., 1999. 'Sociopolitical rank and conical clanship in the Caroline Islands'.

Journal of the Polynesian Society 108(4): 367-410; 368-69 for Micronesia.

29 Davies, 1851; Ellis, 1829.

30 Oliver, 1974, pp. 65-67.

31 Oliver, 1974, p. 1073.

32 Pomare, 1971, pp. 98-100.
} 
According to the American historian Henry Adams, who first came to Tahiti in 1891 and recorded the memories of the elderly female chief Arii Taimai:

Tavi's direct and full authority extended only over his own chiefery of Tautira, but by rank or courtesy, through his family connection or his influence, it extended over the whole island, and only Eimeo or Moorea was exempt. A rahui was a form of corvee to which other great chiefs seldom willingly submitted; but even if a chief were himself anxious to avoid a war, which was the penalty of breaking it, his wife or his sisters or his relations were always ready to urge him to conspire against it. ${ }^{33}$

This description is interesting since it portrays a complex process that goes beyond the idea, often prevalent in current literature, that the rahui was the exclusive monopoly of the ari'i or even of a secondary chief. Moreover, this passage seems to imply that no one could impose a rahui outside the territory he directly controlled. In this instance Tavi, the chief of Tautira, established a rahui on the entire island of Tahiti thanks to his family ties. At that time, the nearby island of Moorea was ruled by an ari'i of equal status called Marama. The issue of kinship was not always clear, all the more so because extended families had numerous members, including some with equal social status and therefore potentially contestable rights and obligations.

Although Takau Pomare described the rahui as an institution for the exclusive benefit of the ari'i, she notes that the implementation was more complex:

The rahui of the broken branch prelude the rahui of the products of land. When the uru, the fruit of the breadfruit tree, had reached full maturity, administrators informed the arii who communicated it to the priest. This latter decided the day of avari (its end). Criers, carrying lighted torches, went from house to house to make the announcement, and as soon as the torches were burned out, delegations of men gathered around the feet of the breadfruit. They did not take the first fruits, but broke the branches or took a couple of these fruits and brought it as a special offering to the arii and god represented by the arii and the high priest. ${ }^{34}$

33 Adams, 1964, pp. 27-30.

34 Pomare, 1971, p. 100. 
In other words, while Pomare notes the idea that the rahui was declared or lifted by the ari'i, she also describes a procedure that required the consent of several other authorities such as 'administrators' and a 'priest'.

According to Handy, the criers mentioned by Pomare are the vea (messengers of the ari'i). ${ }^{35}$ Nevertheless, Pomare's descriptions are ambiguous. Does what she describe apply to the exclusive territory of a chief or to several larger territories, including those on which the chief has indirect control, as Adams maintains? The sources remain coherent on the first issue, but diverge on the second.

The idea of a plurality of authority in the establishment of a rahui is mostly recognised by the eighteenth-century English beachcomber J. Morrison. An unusually astute and perceptive foreign observer of Tahitian culture, his testimony is all the more important and relevant as he was the direct witness of the traditions he described:

The chiefs, toofa and raatira, may declare at their pleasure the rahui on such and such provisions, livestock, fish, within their jurisdiction and where they consider necessary to prevent excessive consumption of pigs, they decree a rahui in the entire district. The King may decree the rahui in several districts and sends instructions accordingly to the chiefs, toofa and raatira to prohibit the consumption or transportation of such or such food in such and such districts or properties for a specified time. ${ }^{36}$

Morrison's words seem more explicit: all types of leaders (ari'i, toofa, raatira) may declare a rahui only on territories under their control. The implementation of a rahui on territories they did not directly control required the consent of other leaders who also directly controlled their own territory. This testimony concurs with that of Adams $^{37}$ and casts doubt on Takau Pomare's assertion about the rahui as the exclusive privilege of the ari' $i .^{38}$ Besides, the social organisation in which the rahui was implemented is congruent with what we know about land tenure in Polynesian societies in the pre-European period..$^{39}$

35 Handy, 1971, p. 74.

36 Morrison, 1966, p. 161.

37 Adams, 1964.

38 Pomare, 1971

39 Oliver, 1974; Crocombe, R., 1987. Land Tenure in the Pacific. 3rd edn. Suva, Fiji: University of the South Pacific; Oliver, D., 1989. Oceania: The Native Culture of Australia and the Pacific Islands. University of Hawai'i Press. 
As a matter of fact, the idea that the ari'i had a monopoly on control over land - an idea often defended by informants with high political status in traditional Polynesian society (priest or ari'i) - appears to have its origin in European colonial ideology. Missionaries and colonial administrators apprehended Polynesian society through the categories of the European feudal model of land tenure. The theory of the 'eminent domain', taken from ancient French law, was a tool with which to substitute the theoretical power of Polynesian chiefs on land for the power of the colonial state. When this reform was completed, the state could establish individualised tenure, which opened the way for fragmented ownership among local and absentee landowners. ${ }^{40}$ Last but not least, it is noteworthy that Adams ${ }^{41}$ and Morrison $^{42}$ evoke the tradition of the rahui in which only the highest ranked individuals of society are involved. A lower social status, such as the manahune, is omitted. As suggested below, this omission is not justified in the traditions.

Before proceeding further with analysis of sources on rahui, it is vital to establish the real meaning of the notion of 'territory'. In particular, are marine territories included in territories where the rahui is implemented? What are the specificities of the rahui in this type of territory?

\section{The rahui of the lagoon: What are the differences?}

As paradoxical as it may seem, marine tenure has not received much attention in the anthropology of Oceania, whereas it was and remains a major concern of local populations. ${ }^{43}$ In particular, the question of the nature of user rights associated with lagoons has not been addressed in detail, as compared to research into user rights on land.

Did the same rules of the rahui have to be observed on land and at sea? If so, were there any differences between the two types of territory? Customary law on cultural continuity between land and sea

\footnotetext{
40 Bambridge, 2009.

41 Adams, 1964.

42 Morrison, 1966.

43 Hvding, 1996.
} 
may lead us to conclude that the appropriation of land was enacted the same way as that of the lagoon. In reality, however, there were distinct characteristics between the two types of territory. The lagoon might be seen only as a natural resource - as would be the case for a coconut tree or a pig - and, therefore, customary norms might only allow some privilege in guardianship and access. This is a significant distinction that emphasises the larger framework of existing rights of use involving land and sea. Were these rights similar? Did they have the same effect? Was there any continuity between the laws of appropriation or were there discontinuities between the two areas so that the rights of use on land might differ to those at sea?

Morrison describes the establishment of a rahui on the lagoon during the visit of some foreigners:

The rahui on reefs is indicated by placing shrubs along the forbidden part with small pieces of cloth and from their appearance no one would dare to fish for fear of losing their land but they can fish with nets, hooks, etc ... in their canoes, the beach is prohibited if they can use their boat, under any pretext. But this only happens when the royal flags go through a territory. ${ }^{44}$

Various reports can be found as to the implementation of rahui on the reef or on the coast.

Certain principles seem to have operated, depending on the context. On the one hand, a rahui on fish would not differ from a rahui imposed on pigs, for they were considered a resource in both cases. The status of the coral reef was more ambiguous. Was the coral reef viewed as a prolongation of land, or as a natural resource? In this respect, Ellis's report is informative in its description of the territorial categorisation of the lagoon:

if the proprietors of the land on the coast wish to preserve the fish of the adjacent sea, they rahui, or restrict, the ground, by fixing up a pole on the reef or shore, with a bunch of bamboo leaves attached to it. By this mark it is understood that the fish are tabu, and fishing prohibited; and no person will trespass on these parts, without the consent of the proprietor. ${ }^{45}$

44 Morrison, 1966, p. 167.

45 Ellis, 1829, p. 286. 
According to Ellis's description, the portion of sea close to land was considered the same way as if it was land. Nevertheless, in a traditional Polynesian context, it would be incorrect to speak of 'property rights' in a Western sense, as far as land and sea are concerned. Actually, the type of ownership that some Polynesians could enjoy refers to some privileged control or mastering of land or of a resource. Therefore, it appears that the coral reef should be treated as both a resource and as a marine area subject to certain appropriations. Indeed, the reef appears to be a resource in the sense that it contained crustaceans and fish. By analogy, the reef is no different than a tree that bears fruit and could have a rahui placed on it. Furthermore, the reef was bounded (whereas the tree was marked). According to Morrison:

The rahui on reefs is indicated by placing shrubs along the forbidden part with small pieces of cloth. Thus, the prohibition of these resources took some general rather than some specific character: all resources located in the designated area were subject to a rahui. Finally, according to several testimonies, the political status of the person who implemented the rahui might vary from the arii to the mere landholder. In both case it extends to the beach. ${ }^{46}$

There is limited detail on the establishment of a rahui at sea and the sanctions behind this process, but it is likely that there were some local differences in both respects. In some cases, a rahui could apply to everyone, including the leaders of the extended family, while in other cases, it excluded outsiders or it could be exempt from it by individuals who got the chief's permission. As far as sanctions involving a marine territory are concerned, some of their descriptions are similar to those applied to land. ${ }^{47}$ In some instances, the chief's influence or coercive physical power could suffice to obtain compliance, but it is likely that the chief's intimate or tutelary spirit was frequently invoked. A second respect in which limitations were put upon fishing involved the rahui that was imposed throughout whole districts on specific occasions or during certain periods of the year (taurua arii, pae atua). For example, some restriction could be imposed on some subsistence activities such as fishing - during the mourning period for a person of high status. Indeed, Pomare recalls a prohibition on fishing bonito and

46 Morrison, 1966.

47 Morrison, 1966; Ellis, 1829. 
albacore at the beginning of the open-sea season until several different rituals had been performed..$^{48}$ Infringing such a rahui would result in individuals being subjected to political or religious sanctions.

As previously noted, rahui on land and at sea embodied several kinds of rights, depending on the chief's status. The decision of a leader to remove a rahui on resources implied organisational changes that affected the labour structure. The leader was not the sole decisionmaker concerning rahui. His followers and other chiefs had to be included in the numerous debates. Some of the literature on the Society Islands intimates that the rahui at sea might not be as different as the one on land. Albacore, coral reefs and the first fish could be subject to rahui, as well as the whole lagoon in terms of territory delimited by poles on the reef or on the shore.

The political economy of Tahiti was based on a ramified organisation. A chieftainship could encompass one or more ramages. The elder of the senior ramage was normally the chief, not only of his ramage, but of the whole chieftainship. But, as a ramified organisation, each elder of each ramage was recognised as chief over its own extended family on its own territory. Such recognition implies a recognition of distinctive rights over the control of the land and the lagoon attached to its territory. Among these rights, one must emphasise the power to implement a rahui on the land and the marine territory of its ramage. Such use rights were associated with rahui held by ramages, and were more relative than absolute. On certain occasions and in different contexts, a major chief may have formal rights of rahui on a territory he does not control directly (in terms of the first fruit or the first fish). On other occasions, the right to implement a rahui by a lesser chief of ramages was independent from the privilege of the major chief. Such rights did not only concern land rights but also lagoon territories, as part of the overall territory controlled by ramages in a context of overlapping duties and responsibilities.

This review of the traditions of rahui in a dynamic perspective makes it clear that rahui could be implemented by a plurality of statuses and not only by the mere authority of the ari'i. Another issue, however, 
involves the rights of individuals of lower political status - especially the manahune - and asks whether these groups had any right to impose a rahui on their territory.

\section{The rahui: A ramified institution?}

At least two major questions have still not been addressed concerning the status of those able to impose and police rahui. First, what were the relationships between rahui and the main territorial structure? Second, what were the relationships between rahui and the main familial structure? Answering these questions reveals the extent to which rahui conformed to each social stratum - see the structural concept expressed by Lévi-Strauss ${ }^{49}$ - or, on the contrary, defied all hierarchies, therefore conforming to the concept of society as one large network.

Morrison's names for territorial divisions - districts (fenua), subdistricts (chief shares, patu) and lesser divisions (squire shares, bahooe - probably rahui) - raises the issue of the relationships between the types of territories and rahui..$^{50}$ It is important to note that the former (the territorial division in Morrison's terminology) referred to the residential centre of an extended family gathered around the marae, and the latter (the lesser divisions in Morrison's terminology) referred to a territorial treaty - including land and lagoon subject to one's individual control. The former could be a political and religious centre whereas the latter could be a territorial division. None of the available sources contradict the idea that both elements might represent two different kinds of territorial units. Consequently, the rahui might have been established on a tract of land and lagoon - the former with no households - in areas that were not subject to unitary control.

To better understand Tahitian rahui, it is important to consider the relations between extended families and the rahui. In Social Stratification in Polynesia, Sahlins considered that 'every brother is differentiated to every other in accordance with the respective order

49 Lévi-Strauss, C., 1958. Anthropologie structurale. Paris: Plon.

50 Morrison, 1966. 
of birth'. ${ }^{51}$ In such a view, the rahui is implemented by the chiefs according to the 'closeness of their relationship to the main line of descent'. ${ }^{52}$ Oliver tackled this question by trying to figure out the extent to which the normative right to rahui affected the relations between extended families affiliated to others and assembled around a marae and the rahui. ${ }^{53}$ Oliver asserts:

Let us suppose, that all four units $(\mathrm{ABCD})$ are subdivisions of what was formerly a single kin-congregation, whose ancestral 'temple' was marae A ... In the first place, I believe that the chief of kincongregation A would have had the right of rahui over B, C, and $\mathrm{D}$ as well. Also, I am inclined to believe, but by no means certain, that in term of the ideology of consanguinity, this right of rahui was normatively executed through 'channels', that is, when imposing a general rahui, the chief of A included B by asking the latter's chief to impose it, and not by direct order to B's whole congregation. ${ }^{54}$

If Oliver's general assumption about the process of social organisation and the rahui as a ramified institution is accepted, many questions still remain. First of all, little evidence is available as to the obligation for a chief - for example, A - to go through another chief - say B when imposing a rahui on a specific chief - say D. Since Polynesian social organisation is, in practice, functioning through a network of relationships, we may wonder whether or not rahui rights paralleled consanguineous relationships. Actually, in some instances, chief A could impose a rahui on chief C's territory but not on chief B's even though chief A's own ancestor may have been an 'elder brother' of B, 'which among blood relations would have embodied some authority over a younger brother'. ${ }^{55}$ According to Oliver's hypothesis on social and political hierarchy, it is clear that high status in Polynesian society involved clever negotiations between privileged individuals in order to impose a rahui on a territory - at sea or on land - they did not control directly. According to Petersen, Sahlins is implicitly conscious of this issue observing that 'a certain inconsistency in the application

\footnotetext{
51 Sahlins, 1958, pp. 147-49.

52 Sahlins, 1958, pp. 147-49.

53 Oliver, 1974, pp. 650-52.

54 Oliver, 1974, p. 651.

55 Oliver, 1974, pp. 650-52.
} 
of the rule of stratification' ${ }^{56}$ As a result, 'it does not follow that all members of the highest standing large ramage outrank all members of all other ramages'.$^{57}$

Therefore, the rahui was less based on a ramified social organisation than on a network of consanguineous relationships and depended on political hierarchy, various local circumstances and opportunity for decision making.

The above discussion on the institution of rahui implies a conceptual model of authority over the control of land, sea and resources based on a network of privileged consanguineous relationships where political status is the basis of the network. Petersen's analysis of power and kava use in the Caroline Islands shares this position. Because of cross-cutting principles of rank 'the character of political power in Pohnpeian society is vague, ambivalent, contradictory, and virtually impossible to observe'.$^{.8}$

Utilisation of this non-structural approach to consanguineous relationships, contradicts Lévi-Strauss's perspective by inferring that all statuses may have had some degree of authority on a rahui, including lower status such as the manahune. ${ }^{59}$ Evidence is limited to categorically support this viewpoint and only Ellis alludes to it in his work.$^{60}$ Of course, it is likely that only the chief of the congregation, whether he is an ari'i, a raatira (secondary chief) or a manahune, could have the authority to enforce a rahui on his land or the sea adjacent to the land he controls, as a family land.

A careful review of the literature around the issue of rahui in the Society Islands before European influence confirms the idea that the rahui was indeed a fundamental political institution in Polynesian society. The above survey supports the hypothesis that the rahui was an institution deeply linked to the social organisation, in such a way that a plurality of statuses was engaged in rahui implementation and sanction. Rahui was not the monopoly of the ari'i, but rather an institution shared among all chiefly congregations. One consequence

\footnotetext{
56 Petersen, 1999, p. 386.

57 Sahlins, 1958, p. 142.

58 Petersen, 2005; Petersen, 1999, p. 386.

59 Lévi-Strauss, 1958; Lévi-Strauss, C., 1964. Le cru et le cuit. Paris: Plon.

60 Ellis, 1829, p. 286.
} 
of this finding is that a more complete understanding of rahui requires more detailed discussion of social and political organisation in Society Islands, and Polynesia in general, about the relations between chiefs and the responsibilities, like the rahui, associated with rank. Similarly, Petersen wonders whether other supposedly chiefly societies within the Austronesian sphere lack 'chiefs' as well. ${ }^{61}$

In terms of legal pluralism theory, the facts observed in Tahiti demonstrate why and how an institution such as the rahui was deeply embedded into the social organisation and did not obey any absolute stratification of the society. The plurality and the network of relationships paralleled the political and religious hierarchy. In so doing, it provided a great number of opportunities for decisionmaking within and between kin-congregations. This accounts for the profound plurality of Polynesian society, and because social organisation was pluralistic, a legal pluralistic approach is not only efficacious, but vital.

This analysis has major implications for understanding Polynesian sociopolitical structures of power, especially the strength and status of ramages. It is also a contribution to the better understating of the relationships between religious power and what might crudely be coined secular power, a problematic dichotomy for Polynesian societies. This essay not only demonstrates more variation across space in rights to apply rahui than is commonly recognised in the secondary literature, but also a wider range of sociopolitical groups able to apply rahui than is commonly acknowledged. Rahui is seen as an evolving process defined by enactment rather than as a static set of rules along the lines of Hviding's account for marine tenure in Marovo lagoon, and Sahlins's account of conical clans. ${ }^{62}$

The restitution of a rich and nuanced account of rahui in the Society Islands shows it as a varied and diverse institution, able to be deployed by different individuals and groups in different contexts. This analysis represents a major departure from the standard 
interpretations popularised by Firth,${ }^{63}$ Sahlins, ${ }^{64}$ Keesing, ${ }^{65}$ and Shore ${ }^{66}$ in Oceanian anthropology, according to which only higher chiefs could implement tapu through their mana. Rahui, like tapu and mana, appear much more localised in application and power source, but also tied to sociopolitical alliances and linkages for wider application. The methodological implications of this conclusion are the need for more local archival work and primary research as well as familiarity with secondary debates and current themes of Polynesian sociopolitical societies. 
This text is taken from The Rahui: Legal pluralism in Polynesian traditional management of resources and territories, edited by Tamatoa Bambridge, published 2016 by ANU Press, The Australian National University, Canberra, Australia. 